\title{
PERFORMANCE ON BIOMASS GASIFICATION OF GROUNDNUT SHELL IN DOWN DRAFT FIXED BED REACTER
}

\author{
SETHURAMAN $\mathbf{N}^{1}$, THAMIZHVEL $\mathbf{R}^{2}$ \& VINODRAJ.S ${ }^{3}$ \\ ${ }^{1,3}$ Associate Professor, Department of Mechanical Engineering, IFET College of Engineering, Villupuram \\ ${ }^{3}$ Assistant Professor, Department of Mechanical Engineering, IFET College of Engineering, Villupuram
}

\begin{abstract}
Biomasses down draft reactors, coupled with reciprocating internal combustion engines are a variable technology to produce heat and power generation. Gasification of biomass is a thermo-chemical conversion process where the carbonaceous feed stocks are partially oxidized into a mixture of gases consisting of hydrogen, carbon monoxide, carbon dioxide and methane, commonly known as producer gas. Gasification of biomass is a renewable and sustainable option for hydrogen generation. Producer gas can be used for hydrogen generation and for combined heat and power (CHP) applications. Producer gas engines working in dual fuel mode with diesel and modified natural gas engines with 100\% producer gas substitution are currently in use. Gasification parameters like reactor temperature (T), equivalence ratio (ER) and steam to biomass ratio (SBR) play major roles in determining quantity and quality of the gasification products. Generally in biomass gasification, locally available feed stocks are preferred. Among the various biomasses available, the feasibility of groundnut shell as a feedstock for gasification in a down draft fixed bed gasifier has been investigated experimentally in terms of gas composition particularly hydrogen content. The hydrogen yield in air gasification mode reached a maximum of $12.45 \%\left(\right.$ Vol. \%) at an operating condition of $T=760^{\circ} \mathrm{C}$ and $\mathrm{ER}=0.24$. A maximum hydrogen yield of $14.7 \%$ (Vol. \%) was obtained during air-steam gasification when the operating conditions were maintained at reactor temperature of $740{ }^{\circ} \mathrm{C}, \mathrm{ER}=0.26$ and $\mathrm{SBR}=0.3$

KEYWORDS: Gasification, Down Draft Fixed Bed Gasifier, Hydrogen Yield, Producer Gas
\end{abstract}

Received: Jun 10, 2020; Accepted: Jun 30, 2020; Published: Jul 27, 2020; Paper Id.: IJMPERDJUN2020470

\section{INTRODUCTION}

Demand for energy has been steadily increasing with the increasing in global population and the rise of living standards. The growing energy demands coupled with restricted fossil fuel options, geo-politics of oil and environmental apprehensions demand the need for sustainable energy generation. Sustainable energy generation focuses on environmentally clean renewable energy resources that are cheap and abundantly available. In this framework of energy generation, the production of hydrogen from carbon neutral biomass has become important. Biomass is a naturally available renewable carbon resource that assures the sustainability of energy supply in the long term basis reducing the shock on the environment. Energy can be extracted from biomass by different conversion ztechnologies like combustion, pyrolysis, gasification, fermentation and anaerobic digestion for the production of heat and electricity, liquid and gaseous transportation fuels, biogas etc. Among the thermo-chemical methods, gasification offers superiority to other technologies of biomass processing [1].Gasification is a thermochemical conversion process where the biomass, is partially oxidized in to a combustible gas mixture at around $800^{\circ} \mathrm{C}$ [2]. The gas mixture - the producer gas - containing hydrogen, carbon monoxide, carbon dioxide and methane, is more suitable and versatile energy carrier which can be used as a feed stock for generating hydrogen or 
for CHP applications. India being an agrarian economy relies heavily on biomass resources including various agricultural and forestry residues. Present day availability of biomass in India is calculated at about 500 million metric tons per year [3]. Considering the Indian context, abundant biomass resources including various agricultural and forestry residues are locally available. Among the various biomass resources available, the feasibility of groundnut shell as a feedstock for gasification is considered. India is the second largest producer of groundnut having an annual production around 1.5 to 2 million tons [4]. A substantial amount of shell residue is produced in the de-hulling process as the shells account for about $20 \%$ of the dried groundnut by weight [4]. It is of interest to investigate the feasibility of groundnut shell as a feedstock for gasification experimentally in terms of gas yield with an impetus on the hydrogen generation capability. The enhancement of hydrogen yield and percentage composition in the combustible gases generated depends on the type of gasifier, gasification media, physico-chemical properties of biomass and the operating parameters. A detailed review of the factors influencing the biomass gasification have been conducted by Alimuddin et al. [5], Parthasarathy et al. [6] Ahmad et al. [7] and Sikarwar et al. [8]. The end use of the producer gas generated is determined by the quality and the quantity of the generated gas. Producer gas with low tar and particulate matter gas can be directly used for power generation in internal combustion engines. Very low sulphur content in producer gas composition is an added advantage Research activities on the use of producer gas in internal combustion engines have been reported [9]- [12].In this study, an experimental investigation on gasification of groundnut shell in a bubbling down draft fixedbed gasifier is carried out to assess the hydrogen yield. The effect of operating parameters temperature, equivalence ratio and steam to biomass ratio in enhancing hydrogen yield has been investigated. The gasification is carried out in a bubbling down draft fixedbed (BFB) gasifier. These types of gasifiers are flexible to a wide variety of biomass and provide a high rate of heat transfer between bed materials and fuel and exhibit approximately uniform temperature distribution throughout the reactor [5]. Further, BFB gasifiers are also capable of generating uniform producer gas with low content of tar and unconverted carbon.

Experimental investigations on air gasification have been reported by researchers like Narvaez etal. [13], Caballero et al.[14], Skoulou et al. [15], and Esfahani et al. [16]. Preliminary investigations carried out in air-steam gasification have been reported by Turn et al. [17] and Lv etal. [18]. Campoy et al. [19] observed that addition of small amount of steam to air in gasification can significantly alter the gas composition by enhancing the reforming reactions. Kumaret al. [20] and Loha et al. [21] have investigated air-steam gasification with distiller's grains and rice husk, respectively, as biomasses. In the present work experimental investigations are carried out with both air and air-steam as gasification agents. Feasibility of producer gas generated for power generation in internal combustion engine is also discussed.

Table 1: Characteristics of Groundnut Shell

\begin{tabular}{|c|c|c|c|c|c|}
\hline \multirow{4}{*}{$\begin{array}{l}\text { BIOMASS } \\
\text { GROUND } \\
\text { NUT } \\
\text { SHELL }\end{array}$} & \multicolumn{5}{|c|}{ Ultimate Analysis } \\
\hline & $\mathbf{C}$ & $\mathbf{H}$ & $\mathbf{O}$ & $\mathbf{N}$ & $\mathbf{S}$ \\
\hline & 42.07 & 6.86 & 50.52 & 1.05 & 0 \\
\hline & \multicolumn{5}{|c|}{ Proximate Analysis } \\
\hline & FC & MC & VM & $\mathrm{AC}$ & \\
\hline & 15.8 & 14.7 & 66.1 & 4.2 & \\
\hline
\end{tabular}

FC- Down draft fixed Carbon MC - Moisture Content

VM- Volatile Matter AC-Ash Content 


\section{MATERIAL AND METHODS}

\section{Material}

Powdered groundnut shells of size 400 to 500 microns are used as the biomass feed. The results of proximate and ultimate analysis of groundnut shell are shown in Table 1. Ultimate analysis has been carried out to determine the elemental composition $(\mathrm{C}, \mathrm{H}, \mathrm{O}, \mathrm{N}$, and $\mathrm{S}$ ) of biomass in weight percentage. The results obtained have been used to calculate stoichiometric air requirement and higher heating value (HHV). Laboratory developed procedures based on prescribed ASTM standards have been used to carry out proximate analysis in this study. These procedures are selected to reduce complexity and time required for the analysis.

\section{Methods}

The experiments were performed in a bubbling down draft fixedbed gasifier suitable for gasifying all types of agricultural wastes in the powdered form having moisture content less than 20\%. A schematic diagram of the setup is shown in Fig. 1. It can be operated in the range $650-850^{\circ} \mathrm{C}$ at a pressure slightly above atmospheric pressure. The feed rate can be varied between $10 \mathrm{~kg} / \mathrm{h}$ to $22 \mathrm{~kg} / \mathrm{h}$ depending on the biomass considered. The air is supplied in such a way that the equivalence ratio is within 0.20

0.45 which is suitable for gasification. The steam feed rate can be varied from 3 to $10 \mathrm{~kg} / \mathrm{h}$ depending on the SBR selected

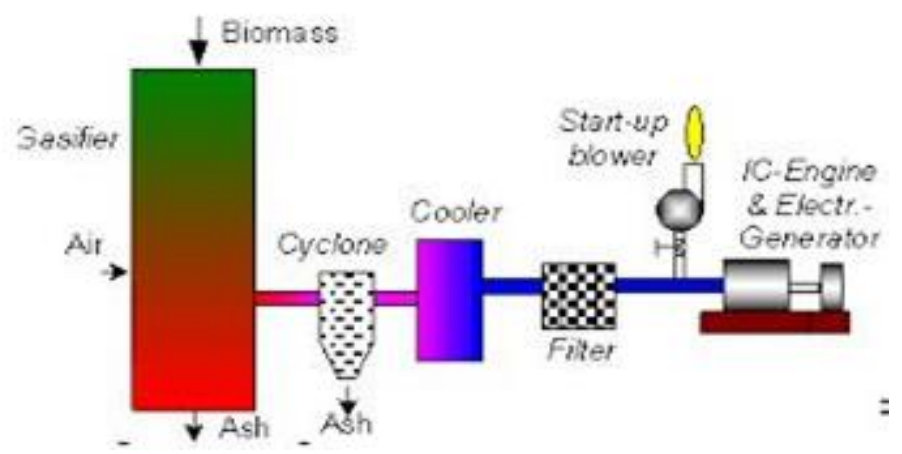

Figure 1: Schematic Diagram for Gasification.

The experimental setup consists of a bubbling down draft fixed bed gasifier, gas cleaning unit, steam supply unit and control and monitoring devices. The bubbling down draft fixed bed gasifier (BFBG) consists of a cylindrical reactor column of $2.30 \mathrm{~m}$ height. Reactor column has a multi-layer insulation to reduce heat losses. The inner most cylindrical core of $150 \mathrm{~mm}$ diameter is made of refractory material capable of withstanding temperature up to $1500{ }^{\circ} \mathrm{C}$. The reactor column has three sections - heating chamber, gasification chamber and the expanded free board chamber. The top portion of the gasifier chamber is enlarged in order to settle the unburnt biomass. In the heating chamber the biomass is heated to gasification temperature in a down draft fixed bed. The down draft fixed bed consists of a bed of inert particles such as sand (granular river sand of size $1 \mathrm{~mm}$ ) supported by a distributor plate. Air is blown through distributor plate with the help of air inlet blower to fluidize the sand bed. Biomass is fed to the gasification chamber through a feed screw fitted with a hopper. The feed rate can be varied by controlling the speed of feed screw motor. The products of gasification from the reaction chamber are taken out of the gasification chamber using a gas suction blower. The suction blower helps in preventing excess pressure build up inside the riser. The producer gas generated in the gasifier is conditioned by passing 
through the gas cleaning unit. The cleaning unit consists of a cyclone separator, a water scrubber, moisture remover and oil scrubber. The monitoring devices consist of thermocouples, manometers, flow meters, RPM indicators and producer gas analyser to measure temperature, pressure, air and steam supply rate, biomass feed rate and producer gas compositions, respectively. Control devices are provided for setting temperature and regulating air, steam and biomass feed rates.

\section{Investigation Procedure}

Groundnut shell with particle size of 400 - 500 microns and having moisture content less than $15 \%$ is collected and stored. Feed rate of the biomass feed screw is calibrated by varying the rpm with respect to the ER for the biomass to be gasified. $1.8 \mathrm{~kg}$ bed material - river sand - is loaded in the gasifier. The heating chamber is brought to the preset temperature of 700 ${ }^{\circ} \mathrm{C}$ using heating coils, which takes about 4-5 hours. Biomass is fed continuously and the air supply is slowly increased to promote the combustion of the biomass so as to increase the heating chamber temperature to $700{ }^{\circ} \mathrm{C}$. Air supply rate and biomass feed rate are properly controlled to maintain this temperature. The suction air blower is switched on to ensure the free exit of the producer gas. As the temperature stabilizes, feed rate is increased slowly to achieve gasification. Exit gases are flared to examine continuous gasification. The gas composition is measured using the gas analyser. Different operating conditions are achieved by varying the biomass feed rate without changing the air supply rate and also controlling the electrical heat input into the reactor chamber. Steam at $250{ }^{\circ} \mathrm{C}$ and 2 bar is supplied at pre-down draft fixed flow rate in the case of air-steam gasification.

\section{RESULTS AND DISCUSSION}

\section{Effect of Operating Parameters}

Effects of operating parameters on gas yield especially hydrogen yield are discussed comparing the air-steam gasification mode and air gasification mode in the case of down draft fixed bed gasification of groundnut shell. The investigation on air- steam gasification is carried out in the temperature range $\left(660-740{ }^{\circ} \mathrm{C}\right)$ at $\mathrm{ER}=0.26$ and $\mathrm{SBR}=0.3$ keeping the biomass feed rate as $16.9 \mathrm{~kg} / \mathrm{h}$, air supply rate as $21.3 \mathrm{~kg} / \mathrm{h}$ and steam flow rate as $5 \mathrm{~kg} / \mathrm{h}$. Air gasification is carried out in the temperature range $660{ }^{\circ} \mathrm{C}-820^{\circ} \mathrm{C}$ with three different equivalence ratios $0.24,0.28$ and 0.32 having biomass feed rate $18.3 \mathrm{~kg} / \mathrm{h}, 15.7 \mathrm{~kg} / \mathrm{h}$ and $13.7 \mathrm{~kg} / \mathrm{h}$, respectively. During the process air supply rate was maintained as $21.3 \mathrm{~kg} / \mathrm{h}$.

Table 2: Producer Gas Composition At Different Operating Condition

\begin{tabular}{|l|c|c|c|c|c|c|}
\hline \multirow{2}{*}{ Parameter } & OPC & OPC & OPC & OPC & OPC & OPC \\
\cline { 2 - 7 } & I & II & III & IV & V & VI \\
\hline T $\left({ }^{\circ} \mathbf{C}\right)$ & 675 & 710 & 710 & 725 & 725 & 735 \\
\hline ER & 0.22 & 0.22 & 0.23 & 0.25 & 0.3 & 0.38 \\
\hline SRR & 0 & 0 & 0 & 0.3 & 0 & 0.2 \\
\hline H2 \% & 10.8 & 11.08 & 12.88 & 10.15 & 9.32 & 12.5 \\
\hline CO\% & 10.4 & 11.56 & 11.52 & 10.59 & 10.17 & 11.28 \\
\hline $\mathbf{C H 4 ~ \% ~}$ & 8.1 & 6.72 & 12.86 & 8.7 & 8.52 & 13.8 \\
\hline $\mathbf{L H V}$ & 5.32 & & & & & \\
\hline & & 5.24 & 5.8 & 5.12 & 5.45 & 6.32 \\
\hline
\end{tabular}

Table 2 elucidates the producer gas composition for down draft fixedbed gasification of groundnut at different operating conditions (OPC I- OPC VI) with and without steam addition. It can be observed from Table 2 that gasification is influenced by the operating parameters: temperature (T), Equivalence ratio (ER) and steam to biomass ratio (SBR). Comparing the operating conditions OPC I and OPC II, it is observed that hydrogen yield is more in the case of OPC II 
which is having a higher operating temperature. The effect of SBR on gasification can be observed by comparing the operating conditions OPC II and OPC III. The influence of higher ER in air-steam gasification mode which tends to reduce the hydrogen yield is nullified by the presence of steam in the reaction system. By comparing operating conditions OPC IV and OPC V it can be found that as ER increases hydrogen yield decreases. Maximum hydrogen yield was obtained in the operating condition OPC VI when the gasifier was operated in the air-steam gasification mode.

\section{Effect of Temperature}

In both air and air steam gasification hydrogen yield increases with temperature. In air gasification mode (Fig. 2) hydrogen yield increases from $10.2 \%$ to $12.45 \%$ as temperature increases from $680{ }^{\circ} \mathrm{C}$ to $760{ }^{\circ} \mathrm{C}$. However air-steam gasification mode (Fig. 3) hydrogen concentration in the producer gas increases from $10.6 \%$ to $14.8 \%$ as temperature increases from $650{ }^{\circ} \mathrm{C}$ to $730^{\circ} \mathrm{C}$. The increase in hydrogen in both cases can be attributed to the enhancement of endothermic gasification reactions. The increase in carbon monoxide and decrease in carbon dioxide is also due to the enhancement of gasification reactions with temperature. Methane shows a decreasing trend initially due to the steam reforming endothermic reactions. The increasing trend in methane at higher temperature may be due to tar cracking.

\section{Effect of Steam to Biomass Ratio}

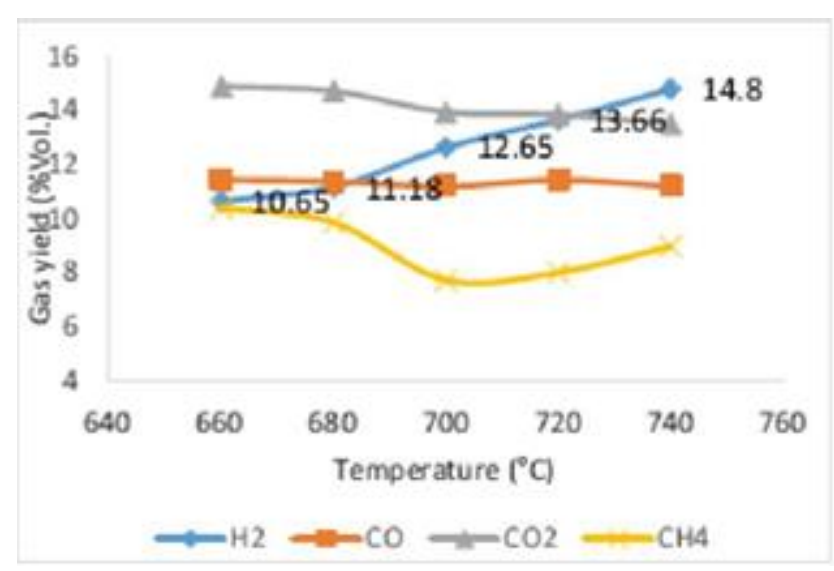

Figure 2: Biomass Ratio Temperature Vs Gas Yield.

The effect of adding steam to air in gasification can be studied comparing the gas yield, especially hydrogen, in air only and air-steam modes of operation. Comparing the results of the experimental investigations illustrated in Fig. 2 and Fig. 3 it can be concluded that there is a pronounced effect in hydrogen yield due to the mixing of steam with air. Air gasification mode at an operating condition $\left(\mathrm{T}=740^{\circ} \mathrm{C}\right.$ and $\left.\mathrm{ER}=0.24\right)$ gives producer gas having a hydrogen concentration of $11.9 \%$ whereas air-steam gasification mode with operating condition $\left(\mathrm{T}=740{ }^{\circ} \mathrm{C}, \mathrm{ER}=0.26\right.$ and $\left.\mathrm{SBR}=0.3\right)$ yields producer gas with $14.8 \%$ of hydrogen (\% Vol.). The marked effect in hydrogen yield is due to the promotion of water gas shift reaction stimulated by the addition of steam in the reaction system. The steam addition is expressed in terms of SBR with indicates the amount of steam $(\mathrm{kg})$ added per unit mass of biomass. It is observed that as SBR increases hydrogen yield also increases. A decrease in carbon monoxide and increase in carbon dioxide is observed as SBR increases.

\section{Effect of Equivalence Ratio}

The effect of equivalence ratio (ER) on gasification is more pronounced in air gasification as denoted in Fig. 4. It is observed that hydrogen yield decreases with increase in ER. As ER increases from 0.24 to 0.32 , hydrogen yield decreases from $11.9 \%$ to $9.58 \%$. Carbon monoxide yield also decreases with increase in ER. An increase in carbon dioxide is 
generally observed with increase in ER. The decrease in hydrogen, carbon monoxide and methane with ER is mainly attributed to the intensified oxidation in the presence of more oxygen in air.

\section{Feasibility of Producer Gas for Internal Combustion Engines}

Producer gas is a mixture of combustible gases like hydrogen, carbon monoxide and methane along with incombustible gases like carbon dioxide, nitrogen and water vapour. The heating value of producer gas generated through air or air steam gasification based on combustible components is in the range 4 to $7 \mathrm{MJ} / \mathrm{Nm} 3$. Properly cleaned low tar Content and low particulate matter producer gas can be used in internal combustion engines

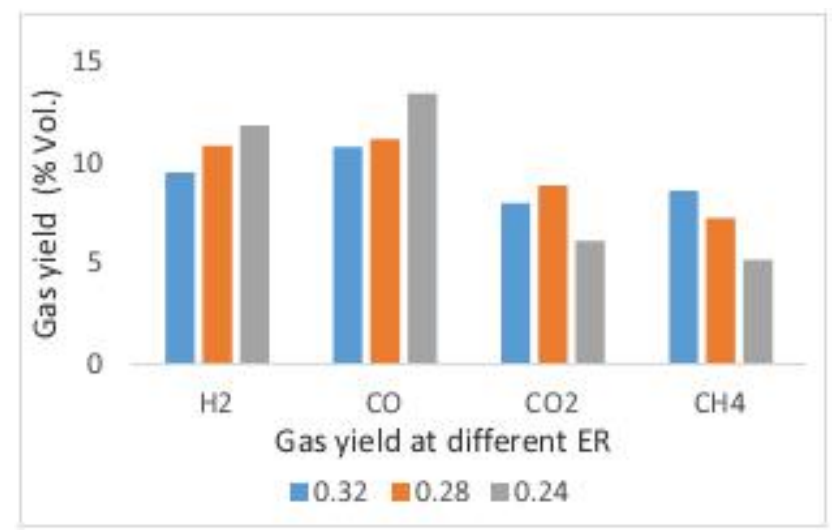

Figure 3: Gas Yield at Different ER Vs Gas Yield.

Producer gas engines working in dual fuel mode with diesel and modified natural gas engines with $100 \%$ producer gas substitution have been tried. Reduction in specific diesel consumption is reported when operated in dual fuel mode. However, reduction in efficiency and rated power has also been reported.

- Even then producer gas engines find wide application in rural sector for decentralized power generation systems with or without fuel substitution

- Further research activities in this field have to be strengthened

\section{CONCLUSIONS}

The investigations of biomass gasification of groundnut shell have been conducted to assess the feasibility of the gasifier by using groundnut shell in a down draft fixedbed system. Gasification of groundnut shell is carried out in air and air steam gasification modes. Hydrogen yield obtained in both cases have been satisfactory. The feasibility of groundnut shell for gasification enhances the end use value. The operating conditions for gasification were selected based on the experimental trials conducted on the setup. Under these test conditions hydrogen yield in air gasification mode reached a maximum of $12.45 \%$ by volume at an operating condition of $\mathrm{T}=760{ }^{\circ} \mathrm{C}$ and $\mathrm{ER}=0.24$. In air-steam gasification mode hydrogen yield reached a maximum of $14.8 \%$ at an operating condition of $\mathrm{T}=740{ }^{\circ} \mathrm{C}$ ER $=0.26$ and $\mathrm{SBR}=0.3$. There is further scope for investigation for enhancing the hydrogen yield by using catalyst and sorbents for tar reduction and carbon dioxide removal. This will enhance the quality of producer gas for internal combustion engine application.

\section{REFERENCES}

1. H. Balat and E. Kirtay, "Hydrogen from biomass - Present scenario and future prospects," Int. J. Hydrogen Energy, Vol. 35, No. 14, pp. 7416-7426, Jul. 2010. 
2. M. Balat, M. Balat, E. Kirtay, and H. Balat, "Main routes for the thermo-conversion of biomass into fuels and chemicals. Part 2: Gasification systems,” Energy Convers. Manag., Vol. 50, No. 12,pp. 3158-3168, Dec. 2009.

3. MNRE, "Ministry of New and Renewable Energy" 2016. [Online].Available: http://mnre.gov.in/. [Accessed: 16-Oct-2016].

4. P. Bharthare, P. Shrivastava, P. Singh, and A. Ttiwari, "PeanutShell As Renewable Energy Source and Their Utility in Production of Ethanol," Int. J. Adv. Res., Vol. 2, No. 4, pp. 1-12, 2014.

5. Z. Alimuddin, B. Zainal, P. Lahijani, M. Mohammadi, and A.Rahman, "Gasification of lignocellulosic biomass in down draft fixedbeds for renewable energy development: A review, ’ Renew. Sustain.Energy Rev., Vol. 14, No. 9, pp. 2852-2862, 2010.

6. P. Parthasarathy and K. S. Narayanan, "Hydrogen production from steam gasification of biomass: Influence of process parameters on hydrogen yield - A review, "Renew. Energy, Vol. 66, pp. 570-579, Jun. 2014.

7. A. A. Ahmad, N. A. Zawawi, F. H. Kasim, A. Inayat, and A. Khasri, "Assessing the gasification performance of biomass: A review on biomass gasification process conditions, optimization and economic evaluation," Renew. Sustain. Energy Rev., Vol. 53, pp. 1333-1347, 2016.

8. V. S. Sikarwar, M. Zhao, P. Clough, J. Yao, X. Zhong, M. Z.Memon, N. Shah, E. Anthony, and P. Fennell, "An overview of advances in biomass gasification, " Energy Environ. Sci, 2016.

9. M. K. Ghosal, D. K. Das, and S. P. Dash, "Performance Study of a Diesel Engine by using producer gas from Selected Agricultural Residues on Dual-Fuel Mode of Diesel-cum-Producer gas, ” in World Renewable Energy Congress 2011, 2011, pp. 3541-3548.

10. P. Raman and N. K. Ram, "Performance analysis of an internal combustion engine operated on producer gas, in comparison with the performance of the natural gas and diesel engines, " Energy, Vol. 63, pp. 317-333, 2013.

11. P. Gobbato, M. Masi, and M. Benetti, "Performance analysis of a producer gas-fuelled heavy-duty SI engine at full-load operation," Energy Procedia, Vol. 82, pp. 149-155, 2015.

12. M. A. A. Efendi and N. Nurhadi, "Comparison of an Internal Combustion Engine Derating Operated on Producer Gas from Coal and Biomass Gasification," Int. J. Adv. Sci. Eng. Inf. Technol., Vol. 6, No. 3, pp. 385-389, 2016.

13. N. Ian, A. Orio, M. P. Aznar, and J. Corella, "Biomass Gasification with Air in an Atmospheric Bubbling Down draft fixed Bed. Effect of Six Operational Variables on the Quality of," Ind. Eng. Chem. Res., Vol. 5885, No. 95, pp. 2110-2120, 1996.

14. M. A. Caballero, J. Corella, A. M. P, and J. Gil, "Biomass Gasification with Air in Down draft fixed Bed. Hot Gas Cleanup with Selected Commercial and Full-Size Nickel-Based Catalysts," Ind. Eng. Chem. Res., No. 39, pp. 1143-1154, 2000.

15. V. Skoulou, G. Koufodimos, Z. Samaras, and a Zabaniotou, "Low temperature gasification of olive kernels in a 5-kW down draft fixedbed reactor for H2-rich producer gas, ”Int. J. Hydrogen Energy, Vol.33, No. 22, pp. 6515-6524, Nov. 2008.

16. R. M. Esfahani, W. A. Wan Ab Karim Ghani, M. A. Mohd Salleh, and S. Ali, "Hydrogen-rich gas production from palm kernel shell by applying air gasification in down draft fixedbed reactor, " Energy and Fuels, Vol. 26, No. 2, pp. 1185-1191, 2012.

17. S. Turn, C. Kinoshita, and D. Ishimura, “An Experimental Investigation of Hydrogen Production,” Int. J. Hydrogen Energy, Vol. 23, No. 8, pp. 641-648, 1998.

18. P. Lv, J. Chang, Z. Xiong, H. Huang, C. Wu, and Y. Chen, "Biomass Air - Steam Gasification in a Down draft fixedBed to Produce Hydrogen-Rich Gas, " Energy and fuels, Vol. 17, No. 3, pp. 677-682, 2003.

19. M. Campoy, A. Go, A. L. Villanueva, and P. Ollero, "Air - Steam Gasification of Biomass in a Down draft fixedBed under Simulated Autothermal and Adiabatic Conditions," Ind. Eng. Chem., pp. 5957-5965, 2008. 
20. A. Kumar, K. Eskridge, D. D. Jones, and M. a Hanna, "Steam-air down draft fixedbed gasification of distillers grains: Effects of steam to biomass ratio, equivalence ratio and gasification temperature” Bioresour. Technol., Vol. 100, No. 6, pp. 2062-8, Mar. 2009.

21. C. Loha, H. Chattopadhyay, and P. K. Chatterjee, "Energy generation from down draft fixedbed gasification of rice husk," J. Renew.Sustain. Energy, Vol. 5, No. 4, p. 43111, 2013

22. Kumar, Grandhi Suresh, Avssks Gupta, and M. Viswanadham. "Experimental Investigation of Co-Gasification of Coal and Biomass with Co2 Capture Using CaO Sorbent." International Journal of Mechanical and Production Engineering Research and Development (IJMPERD) 8.5 (2018):233-240.

23. Sivakumar, S., N. Ranjithkumar, and S. Ragunathan. "Design and development of down draft wood gasifier." International Journal of Mechanical Engineering (IJME) 2.2 (2013): 1-10.

24. Mabasha, D., G. Venkatesh, and K. Jayasimha Reddy. "Production of Synthesis Gas from Biomass and Plastic Waste Using a Updraft Gasifier." International Journal of Mechanical and Production Engineering Research and Development (IJMPERD) 9.5 (2019):457-468.

25. Sharma, Gangaraju Srinivasa, MVS Murali Krishna, and D. N. Reddy. "CFD analysis for adaptability of producer gas for power generation in gas turbines." International Journal of Mechanical and Production Engineering Research and Development (IJMPERD) 5.2 (2015): 21-32.

26. Vidian, Fajri, Hasan Basri Safrialto, and Helmy Alian. "Application of Producer Gas from South Sumatera, Indonesia, Low Rank Coal Gasification on Spark Ignition Engine or Gasoline Engine." International Journal of Mechanical and Production Engineering Research and Development (IJMPERD) 9.5 (2019):611-620 